\title{
Pengaruh Pemberian Ekstrak Buah Mengkudu (Morinda citrifolia L.) Terhadap Aktivasi NF-K $\beta$ dan Ekspresi Protein (TNF- $\alpha$, ICAM-1) pada Kultur Sel Endotel (HUVECs) Dipapar Ox-LDL
}

\author{
Endah Kusuma Rastini ${ }^{1^{*}}$, M. Aris Widodo ${ }^{2}$, M. Saifur Rohman ${ }^{3}$ \\ ${ }^{1}$ Program Studi Biomedik Universitas Brawijaya \\ ${ }^{2}$ Fakultas Kedokteran Universitas Brawijaya \\ ${ }^{3}$ Laboratorium Biokimia Fakultas Kedokteran Universitas Brawijaya
}

\begin{abstract}
Abstrak
Penelitian ini bertujuan mengetahui pengaruh dan mekanisme kerja mengkudu (Morinda citrifolia) terhadap aktivasi NF- $\mathrm{K} \beta$, ekspresi protein TNF- $\alpha$ dan ICAM-1 dalam menghambat proses aterosklerosis. Penelitian dilakukan secara in vitro menggunakan kultur sel endotel vena umbilikalis manusia (HUVECs). Dibuat dua kelompok kontrol pada kultur sel endotel yaitu kontrol negatif tanpa perlakuan, kelompok yang dipapar Ox-LDL $40 \mu \mathrm{g} \mathrm{ml}^{-1}$, Kelompok perlakuan yaitu kultur sel endotel dengan pemberian dosis ekstrak mengkudu $2,5 \mathrm{\mu g} \mathrm{ml}^{-1}, 5 \mathrm{\mu g} \mathrm{ml}^{-1}$ dan $10 \mu \mathrm{g} \mathrm{ml}^{-1}$ selama dua jam. Masing-masing sistem kultur dipapar $\mathrm{Ox}-$ LDL $40 \mu \mathrm{g} \mathrm{ml}^{-1}$. Pemaparan Ox-LDL dilakukan selama 30 menit untuk mengetahui aktivasi NF-k $\beta$ dan 24 jam untuk mengetahui ekspresi protein TNF- $\alpha$ dan ICAM-1. Pengukuran aktivasi NF- $\mathrm{K} \beta$, ekspresi protein TNF- $\alpha$ dan ICAM-1 menggunakan imunohistokimia. Hasil penelitian menunjukkan, ekstrak mengkudu dengan dosis

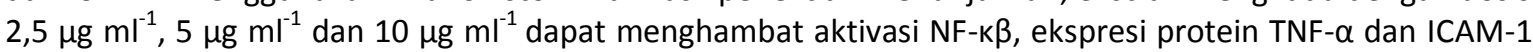

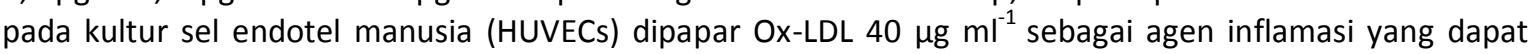
menimbulkan aterosklerosis. Melalui analisis ANOVA $(p<0,01)$ diketahui terdapat hubungan negatif pada perlakuan antar dosis ekstrak mengkudu dalam menghambat aktivasi NF-k $\beta$, ekspresi protein TNF- $\alpha$ dan ICAM-1 menggunakan analisis Spearman's $(p<0,01)$.
\end{abstract}

Kata kunci: aterosklerosis, ICAM-1, mengkudu (Morinda citrifolia L.), NF-K $\beta$, Ox-LDL, TNF- $\alpha$

\section{PENDAHULUAN}

Penyakit aterosklerosis merupakan suatu penyakit kompleks. Aterosklerosis berawal dari penumpukan kolesterol terutama ester kolesterol-LDL (lipoprotein densitas rendah) di dinding arteri. Low Density Lypoprotein (LDL) secara normal bisa masuk dan keluar dari dinding arteri melalui endotel. Masuknya lipoprotein ke lapisan dalam dinding pembuluh darah meningkat seiring tingginya jumlah lipoprotein dalam plasma (hiperlipidemia), ukuran lipoprotein dan tekanan darah (hipertensi). Peningkatan semua itu akan meningkatkan permeabilitas dinding pembuluh darah, sehingga lipoprotein dan ester kolesterol mengendap di dinding arteri.

Salah satu penyakit yang berhubungan dengan terjadinya aterosklerosis adalah penyakit kardiovaskuler, yang diketahui menye-

\footnotetext{
* Alamat Korespondensi:

Endah Kusuma Rastini

E-mail : rastini@gmail.com

Alamat : Program Studi S2 Biomedik Universitas Brawijaya, Jl. Veteran, Malang, 65145
}

babkan kematian terbesar di negara maju seperti Amerika Serikat. Di Indonesia sendiri mulai terjadi pergeseran angka kematian dari penyakit infeksi kepada penyakit metabolik dan degeneratif termasuk juga penyakit jantung koroner dan pembuntuan pembuluh darah otak yang diantaranya disebabkan oleh aterosklerosis. Berdasarkan data penelitian terdahulu telah banyak dibuktikan bahwa aterosklerosis merupakan proses inflamasi atau keradangan kronis. Zat yang merangsang inflamasi maupun protein dihasilkan sel radang terlibat secara langsung sejak awal hingga proses terjadinya komplikasi dari aterosklerosis. Perubahan fungsi endotel akan mengubah perjalanan aterosklerosis.

Pembentukan awal aterosklerosis bermula dari sel darah putih, yang disebut monosit dan $\mathrm{T}$ Limfosit, yang mengalami penumpukan pada dinding pembuluh darah arteri dan dipicu oleh modifikasi LDL. Salah satu modifikasi LDL yang menyebabkan aterosklerosis adalah Ox-LDL [1]. Ox-LDL dapat mengaktifkan faktor transkripsi NFKB yang terlibat dalam ekspresi imun dan 
inflamasi gen. NF-kB yang aktif dapat menginduksi terbentuknya protein pada sistem imun seperti protein sitokin (TNF- $\alpha$, IL-1), adesi molekul (VCAM-1, ICAM-1), dan zat vasoaktif (eNOS, NO). Keadaan ini meningkatkan progresifitas aterosklerosis sehingga mengakibatkan pembuntuan arteri koroner [2].

Salah satu bahan yang dapat mencegah terjadinya aterosklerosis dalam tubuh adalah antioksidan, yang dapat diperoleh dari sayur dan buah. Mengkudu dalam berbagai penelitian diketahui dapat digunakan sebagai antiinflamasi, antibakteri, dan antikanker, di mana memiliki berbagai macam zat aktif.

Mengkudu merupakan tanaman tropis termasuk dalam familia Rubiaceae. Tinggi tanaman mengkudu antara empat sampai enam meter, berdaun hijau lebar dan berbuah sepanjang tahun. Mengkudu sudah sejak lama dikenal sebagai tanaman yang berkhasiat [3]. Mengkudu mengandung zat aktif utama yaitu polisakarida, scopoletin, ascorbic acid, beta carotene, I-arginin, dan enzim proxeronase dari suatu alkaloid pro-xeronin. Zat aktif utama dalam buah mengkudu lebih berperanan dibandingkan dengan zat aktif lain dalam buah mengkudu. Menurut Kamiya, dalam mengkudu, selain antioksidan, zat bioaktif yang diketahui dapat menghambat $O x-L D L$ pada proses atero-sklerosis adalah senyawa polifenol (3,3'-bisdemethylpinoresinol, americanoid acid A, morindolin, americanol A, americanin A, dan isoprincepin). Bioaktif antioksidan dan poli-fenol tersebut dapat menekan teraktivasinya NF- $\kappa B$ sehingga ekspresi protein inflamasi (TNF- $\alpha$, ICAM-1) tidak terbentuk dan proses aterosklerosis dapat dihambat[4].

Mengetahui mekanisme dan pengaruh ekstrak buah mengkudu pada kultur sel endotel (HUVECs) terhadap aktivasi NF- $\kappa B$, penurunan ekspresi protein TNF- $\alpha$ dan ICAM-1 yang memediatori terjadinya aterosklerosis.

\section{METODE PENELITIAN}

Penelitian ini menggunakan eksperimen murni melalui percobaan di laboratorium, dengan tiga kali pengulangan terhadap empat kelompok perlakuan pada kultur sel HUVECs yang diinkubasi dengan Ox-LDL dan satu kultur sel normal.

Pembuatan Kultur Sel Endotel (HUVECs)

Vena Umbilikus dibersihkan dengan larutan PBSA dan diberi larutan Collagenase. Collagenase dikeluarkan dari umbilikus, disentrifugasi kece- patan $1000 \mathrm{rpm}$ selama 8 menit. Supernatan dibuang, ditambahkan $4 \mathrm{ml}$ medium kultur dan dipindahkan ke dalam plate well 24. Plate dimasukkan ke dalam inkubator sampai monolayer (membentuk cobblestone) kurang lebih 3-4 hari dan media diganti setiap 2 hari sekali.

Pembuatan Ekstrak Mengkudu

Bubuk buah mengkudu dimasukkan dalam kertas saring dan diikat kedua ujungnya, direndam dalam gelas ekstraksi sokhlet $250 \mathrm{ml}$ berisi etanol $80 \%$ sampai pekat dan dilakukan ekstraksi. Hasil ekstraksi kemudian dievaporasi (memisahkan antara pelarut etanol dan ekstrak kasar mengkudu).

Pemberian Ekstrak Mengkudu untuk menekan aktivasi NF-k $\beta$, ekspresi protein TNF- $\alpha$ dan ICAM-1

Kultur primer sel endotel monolayer diinkubasi dengan dan tanpa ekstrak buah mengkudu selama 2 jam berbagai dosis, kemudian ditambahkan Ox-LDL dan diamati pengaruhnya terhadap aktivasi NF- $\kappa$ B setelah 30 menit sampai 1,5 jam. Dibuat kultur primer yang sama dengan perlakuan di atas dan diamati peningkatan ekspresi gen TNF- $\alpha$, ICAM-1 setelah 24 jam.

Pengukuran imunohistokimia untuk mengetahui aktivasi NF-k $\beta$, ekspresi protein TNF- $\alpha$ dan ICAM-1

Kultur sel endotel yang telah diberi ekstrak mengkudu dan dipapar Ox-LDL dicuci dengan HEPES buffer selama 30 menit dan difiksasi dengan methanol selama 5 menit. Preparat dikeringanginkan dan dicuci dengan PBS $\mathrm{pH} 7,4$. Diaplikasikan $3 \% \mathrm{H}_{2} \mathrm{O}_{2}$ selama 10 menit dan cuci dengan PBS pH 7,4 pada preparat. Digunakan serum $5 \%$ FBS yang mengandung 0,25\% Triton X100 dan inkubasi selama 1 jam pada suhu ruang untuk bloking. Preparat dicuci dengan PBS pH 7,4 dan ditetesi dengan monoclonal anti p50-p65, monoklonal anti TNF- $\alpha$, monoklonal anti ICAM-1 dan diinkubasi semalam. Preparat dicuci dengan PBS pH 7,4, ditetesi dengan antibodi sekunder berlabel biotin dan diinkubasi selama satu jam. Preparat dicuci dengan PBS $\mathrm{pH} 7,4$ dan ditetesi dengan SA-HRP (Strep-Avidin horse radis peroxidase) selama 40 menit, kemudian dicuci dengan PBS pH 7,4 dan diaplikasikan kromogen untuk HRP, yaitu DAB (3-3'-diamino benzidine). Counterstain dilakukan dengan Mayer hematoxilen selama 10 menit, dibilas dengan air mengalir dan dicuci dengan $\mathrm{dH}_{2} \mathrm{O}$. Preparat dikeringkan dan ditutup coverglass. Hasil diamati 
dengan mikroskop Olympus cx21 perbesaran 1000 kali.

\section{HASIL DAN PEMBAHASAN}

\section{Kultur Sel Endotel (HUVECs) Normal}

Kultur sel endotel (HUVECS) dalam kondisi normal memiliki ciri-ciri antara lain bentuk sel cobblestone, dengan spesifisitas sel pada bagian tengah tampak bulat dan jelas. Selain itu bentuk sel pipih, jarak antar sel teratur dan permukaan sel ditandai dengan kejelasan inti sel, membran plasma, sitoplasma, dan extra cellular matrix (ECM) [5]. Hasil kultur sel endotel dalam kondisi pada penelitian ini dapat dilihat pada Gambar 1.

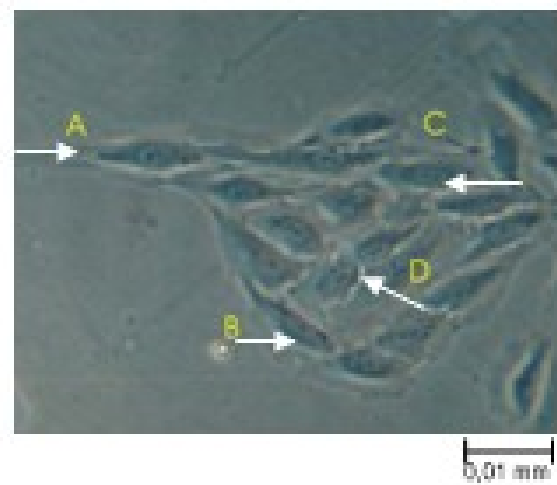

Gambar 1. Kultur Sel Endotel (HUVECs) Dalam Kondisi Normal pada hari ke 4 kultur. Preparat diamati dengan mikroskop inverted nikkon, perbesaran 400 kali

Keterangan:
A. membran sel
B. sitoplasma
C. inti sel
D. extra cellular matrix (ECM)

\section{Optimalisasi Dosis Ekstrak Mengkudu Pada Kultur Sel Endotel}

Hasil eksplorasi atau pemaparan dosis ekstrak mengkudu selama dua jam pada kultur sel endotel normal hari ke-4 menunjukkan bahwa pada dosis tertinggi, yaitu $20 \mathrm{mg} \mathrm{ml}^{-1}$, merupakan dosis yang toksik untuk sel endotel (HUVECs). Keadaan ini ditandai dengan kematian sel (Gambar 2), sel membulat dan terlepas dari media kultur. Beberapa sel yang masih hidup juga mulai mengalami kematian ditandai dengan terjadinya shrinkage (sel mengkerut), jarak antar sel melebar dan sel membulat. Oleh karena itu dosis ekstrak mengkudu yang dapat digunakan adalah $10 \mathrm{mg} \mathrm{ml}^{-1}, 5 \mathrm{mg} \mathrm{ml}^{-1}$, dan 2,5 $\mathrm{mg} \mathrm{ml}^{-1}$.

\section{Optimalisasi Dosis Ox-LDL Pada Kultur Sel} Endotel

Optimalisasi Dosis dilakukan dengan merujuk penelitian terdahulu, yaitu range Ox-LDL yang sesuai pada kultur adalah antara 10-50 $\mathrm{g} \mathrm{ml}^{-1}$. Hasil penelitian menunjukkan, pada penentuan aktivasi faktor transkripsi NF-к $\beta$, setelah kultur sel endotel ditambah dengan ekstrak mengkudu selama dua jam dan kemudian dipapar dengan Ox-LDL $50 \mu \mathrm{g} \mathrm{ml}^{-1}$ selama 30 menit, sel tetap hidup. Ekspresi protein TNF- $\alpha$ dan ICAM-1 ketika dilakukan pengukuran setelah dua jam pemberian dosis ekstrak mengkudu dan dipapar dengan Ox-LDL $50 \mu \mathrm{g} \mathrm{ml} \mathrm{m}^{-1}$ selama 24 jam, sel menunjukkan penurunan viabilitas (Gambar 3). Berdasarkan hasil uji optimalisasi penggunaan kadar Ox-LDL, maka digunakan kadar Ox-LDL sebesar $40 \mathrm{\mu g} \mathrm{ml}^{-1}$ dan dosis ekstrak mengkudu $2,5 \mathrm{mg} \mathrm{ml}^{-1}, 5 \mathrm{mg} \mathrm{ml}^{-1}$, dan $10 \mathrm{mg} \mathrm{ml}^{-1}$ dalam penelitian ini.
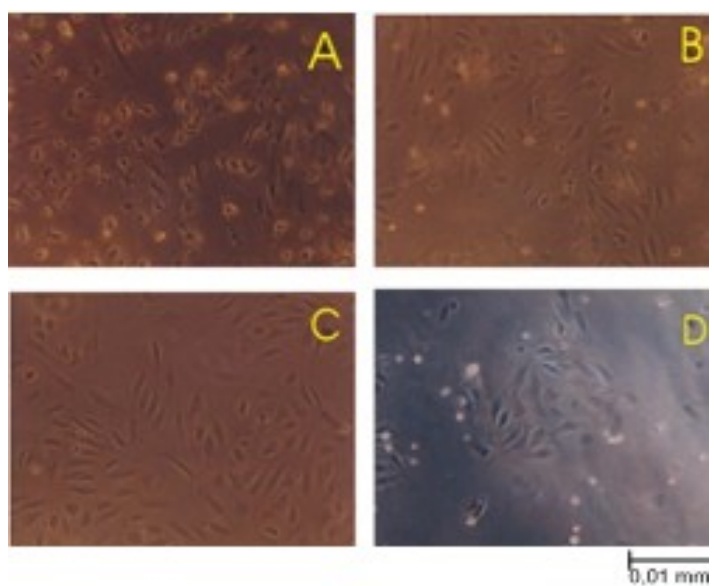

Gambar 2. Kultur Sel Endotel (HUVECs) hari ke 4 dipapar dosis ekstrak mengkudu 2 jam. Diamati dengan mikroskop inverted nikkon, perbesaran 400 kali.

Keterangan:

A. ekstrak mengkudu $20 \mathrm{mg} \mathrm{ml}^{-1}$

B. ekstrak mengkudu $10 \mathrm{mg} \mathrm{ml}^{-1}$

C. ekstrak mengkudu $5 \mathrm{mg} \mathrm{ml}^{-1}$

D. ekstrak mengkudu $2,5 \mathrm{mg} \mathrm{ml}^{-1}$

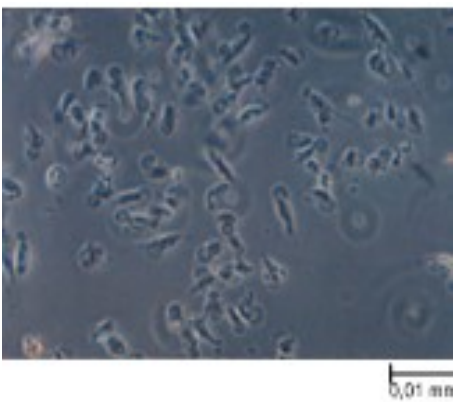

Gambar 3. Kultur sel Endotel setelah diberi ekstrak mengkudu dosis tertinggi 2 jam dan dipapar Ox-LDL $50 \mu \mathrm{g} \mathrm{ml}{ }^{-1}$ selama $24 \mathrm{jam}$. Sel tampak mulai mengalami kematian diamati dengan mikroskop inverted nikkon, perbesaran 400 kali.

Imunohistokimia Aktivasi Faktor Transkripsi NFк $\boldsymbol{\beta}$ Pada Kultur Sel Endotel (HUVECs)

Berdasarkan hasil pengecatan imunohistokimia pada kultur sel endotel (HUVECs yang telah diberi ekstrak mengkudu dosis $2,5 \mathrm{mg} \mathrm{ml}^{-1}, 5$ 
$\mathrm{mg} \mathrm{ml^{-1 }}$, dan $10 \mathrm{mg} \mathrm{ml}^{-1}$ selama dua jam dan dipapar dengan Ox-LDL $40 \mu \mathrm{g} \mathrm{ml^{-1 }}$ selama 30 menit untuk melihat aktivasi NF-k $\beta$ (Gambar 4), dapat diketahui bahwa kultur sel endotel normal tanpa adanya aktivasi NF-k $\beta$ (Gambar 4). Selain itu tampak pula inti sel berwarna biru atau biru keunguan dengan sitoplasma yang jelas dan tampak kecoklatan. Sedangkan pada kultur sel endotel yang menunjukkan adanya aktivasi NF$\kappa \beta$, diperlihatkan pada perlakuan kontrol positif (Gambar 5) dengan penampakan inti sel berwarna biru atau ungu tetapi lebih pucat (warna biru atau ungu samar dan tidak jelas).
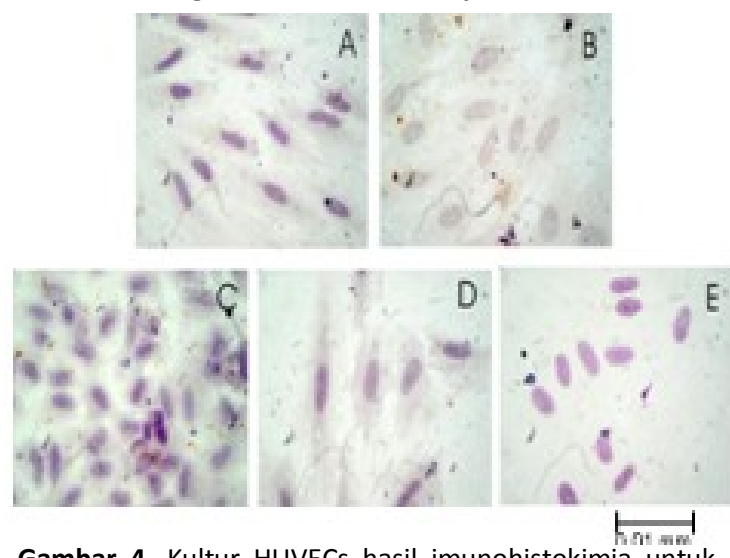

Gambar 4. Kultur HUVECs hasil imunohistokimia untuk melihat aktivasi NF-K $\beta$.

Keterangan:

(A) Kontrol Negatif (tanpa perlakuan) (B) Kontrol Positif (dipapar LDL teroksidasi $40 \mathrm{\mu gml}^{-1}$ ) (C),(D) dan (E) adalah HUVECs diberi ekstrak mengkudu dengan dosis berturutturut 2,5 $\mathrm{mg} \mathrm{ml}^{-1}, 5 \mathrm{mg} \mathrm{ml}^{-1}$, dan $10 \mathrm{mg} \mathrm{ml}^{-1}$ yang dipapar Ox-LDL $40 \mu \mathrm{g} \mathrm{ml}{ }^{-1}$ (diamati dengan mikroskop Olympus cx21, perbesaran 1000 kali).

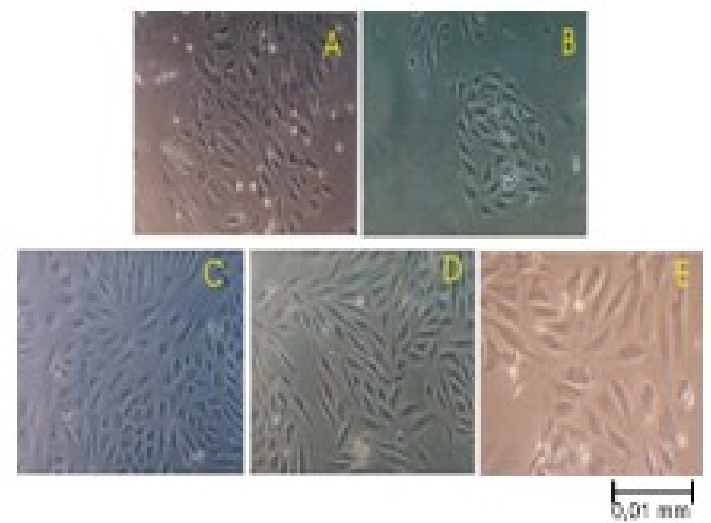

Gambar 5. Kultur Sel Endotel (HUVECs) untuk melihat Ekspresi TNF- $\alpha$ /ICAM-1.

Keterangan:

(A) Kontrol Negatif (tanpa perlakuan) (B) Kontrol Positif (dipapar Ox-LDL $40 \mu \mathrm{g} \mathrm{ml}{ }^{-1}$ ) (C), (D) dan (E) adalah HUVECs diberi ekstrak mengkudu dengan dosis berturutturut 2,5 $\mathrm{mg} \mathrm{ml}^{-1}, 5 \mathrm{mg} \mathrm{ml}^{-1}$, dan $10 \mathrm{mg} \mathrm{ml}^{-1}$ yang dipapar Ox-LDL $40 \mu \mathrm{g} \mathrm{ml}^{-1}$. (Foto dengan perbesaran 400x, mikroskop inverted merk nikkon).
Analisis statistik Oneway ANOVA dan uji Duncan menunjukkan bahwa terdapat pengaruh bermakna pada kultur sel endotel yang dipapar dengan ekstrak mengkudu terhadap banyaknya aktivasi NF-k $\beta$ dalam sel endotel $(p<0,01)$. Hal ini menunjukkan bahwa pemberian ekstrak mengkudu berbagai dosis, yaitu $2,5 \mathrm{mg} \mathrm{ml}^{-1}, 5$ $\mathrm{mg} \mathrm{ml}^{-1}$, dan $10 \mathrm{mg} \mathrm{ml}^{-1}$ menyebabkan penurunan aktivasi NF-k $\beta$ pada kultur sel endotel dipapar Ox-LDL. Berdasarkan analisis di atas menunjukkan bahwa semakin besar dosis ekstrak mengkudu yang diberikan pada kultur sel endotel dipapar Ox-LDL, maka akan semakin menurunkan aktivasi faktor transkripsi NF-k $\beta$ pula.Hasil pengecatan secara imunohistokimia untuk aktivasi NF-k $\beta$ kemudian dilakukan penghitungan sel dan dianalisis dengan analisis statistik Duncan $(p<0,01)$ yang ditunjukkan pada Tabel 1.

Tabel 1. Pemberian Ekstrak Mengkudu pada kultur Sel Endotel dipapar Ox-LDL $40 \mu \mathrm{g} \mathrm{ml^{-1 }}$ terhadap Aktivasi $\mathrm{NF}-\mathrm{K} \beta$

\begin{tabular}{llll}
\hline No & Perlakuan & $\begin{array}{l}\text { Jumlah } \\
\text { Sel }\end{array}$ & $\begin{array}{l}\text { Aktivasi NF-K } \beta \\
([\mathrm{X} \pm \mathrm{SD}] \%)\end{array}$ \\
\hline 1 & $\begin{array}{l}\text { Kontrol } \\
\text { Negatif }\end{array}$ & 251 & $2,21 \pm 7,41^{\mathrm{a}}$ \\
2 & $\begin{array}{l}\text { Kontrol } \\
\text { Positif }\end{array}$ & 175 & $48,41 \pm 17,84^{\mathrm{b}}$ \\
3 & $\begin{array}{l}\mathrm{M}_{1} \\
\left(2,5 \mathrm{ng} \mathrm{ml}^{-1}\right)\end{array}$ & 223 & $0,9 \pm 2,74^{\mathrm{a}}$ \\
4 & $\begin{array}{l}\mathrm{M}_{2} \\
\left(5 \mathrm{ng} \mathrm{ml}^{-1}\right)\end{array}$ & 230 & $0,25 \pm 1,12^{\mathrm{a}}$ \\
5 & $\begin{array}{l}\mathrm{M}_{3} \\
\left(10 \mathrm{ng} \mathrm{ml}^{-1}\right)\end{array}$ & 193 & $0,00 \pm 0,00^{\mathrm{a}}$ \\
\hline
\end{tabular}

Keterangan:

Huruf yang berbeda menunjukkan perbedaan yang nyata berdasarkan analisis statistik Duncan $(p<0,01)$

\section{Imunohistokimia Ekspresi Protein TNF- $\alpha$ Pada Kultur Sel Endotel (HUVECs)}

Kultur sel endotel yang menunjukkan adanya ekspresi protein TNF- $\alpha$, diperlihatkan pada perlakuan kontrol positif (Gambar 6), dengan penampakan inti sel dan sitoplasma berwarna kecoklatan atau merah kecoklatan. Ekspresi protein sitokin TNF- $\alpha$ yang timbul pada kontrol positif kultur sel akibat dari teraktivasinya faktor transkripsi NF-k $\beta$, hasil induksi atau pemaparan Ox-LDL. Gambar hasil pengecatan imunohistokimia menunjukkan bahwa dengan bertambahnya dosis ekstrak mengkudu yang diberikan pada kultur sel endotel (HUVECs) maka ekspresi protein sitokin TNF- $\alpha$ semakin berkurang. Hal ini ditandai dengan semakin berkurangnya warna inti sel yang tampak coklat kemerahan dan semakin banyak inti sel tampak biru keunguan. 


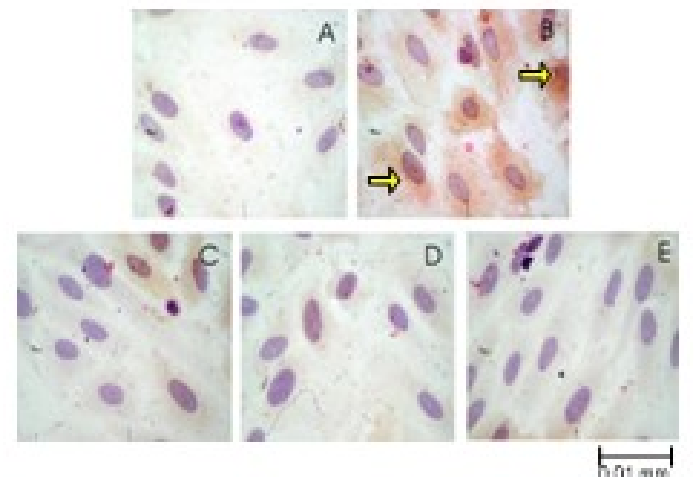

Gambar 6. Kultur HUVECs hasil imunohistokimia untuk melihat ekspresi TNF- $\alpha$.

Keterangan:

(A) Kontrol Negatif (tanpa perlakuan) (B) Kontrol Positif (dipapar Ox-LDL $40 \mu \mathrm{g} \mathrm{ml} \mathrm{m}^{-1}$ ) (C), (D) dan (E) adalah HUVECs diberi ekstrak mengkudu dengan dosis berturutturut 2,5 $\mathrm{mg} \mathrm{ml}^{-1}, 5 \mathrm{mg} \mathrm{ml}^{-1}$, dan $10 \mathrm{mg} \mathrm{ml}^{-1}$ yang dipapar Ox-LDL $40 \mu \mathrm{g} \mathrm{ml}{ }^{-1}$. Preparat diamati dengan mikroskop Olympus cx21 perbesaran 1000 kali.

Berdasarkan penghitungan jumlah kultur sel endotel yang mengekspresikan protein TNF- $\alpha$ paling tinggi terdapat pada perlakuan kontrol positif, di mana kultur sel endotel hanya dipapar Ox-LDL (Tabel 2.). Pemaparan kultur sel endotel menggunakan Ox-LDL meningkatkan produksi TNF- $\alpha$ dalam sel. Sementara perlakuan dengan pemberian ekstrak mengkudu berbagai dosis menunjukkan penurunan ekspresi protein sitokin TNF- $\alpha$, terutama pada dosis mengkudu 10 $\mathrm{mg} \mathrm{ml}^{-1}$ yang merupakan dosis paling tinggi.

Tabel 2. Ekspresi protein sitokin TNF- $\alpha$ pada Kultur Sel Endotel yang Dipapar Ox-LDL $40 \mu \mathrm{g} \mathrm{ml^{-1 }}$ dan Pemberian Ekstrak Mengkudu

\begin{tabular}{llll}
\hline No & Perlakuan & $\begin{array}{l}\text { Jumlah } \\
\text { Sel }\end{array}$ & $\begin{array}{l}\text { Aktivasi TNF- } \alpha \\
([\mathrm{X} \pm \mathrm{SD}] \%)\end{array}$ \\
\hline 1 & $\begin{array}{l}\text { Kontrol } \\
\text { Negatif }\end{array}$ & 147 & $0,00 \pm 0,00^{\mathrm{a}}$ \\
2 & $\begin{array}{l}\text { Kontrol } \\
\text { Positif }\end{array}$ & 267 & $40,28 \pm 16,82^{\mathrm{b}}$ \\
3 & $\begin{array}{l}\mathrm{M}_{1} \\
\left(2,5 \mathrm{ng} \mathrm{ml}^{-1}\right)\end{array}$ & 223 & $1,97 \pm 4,16^{\mathrm{a}}$ \\
4 & $\begin{array}{l}\mathrm{M}_{2} \\
\left(5 \mathrm{ng} \mathrm{ml}^{-1}\right)\end{array}$ & 230 & $0,74 \pm 2,28^{\mathrm{a}}$ \\
5 & $\begin{array}{l}\mathrm{M}_{3} \\
\left(10 \mathrm{ng} \mathrm{ml}^{-1}\right)\end{array}$ & 193 & $0,00 \pm 0,00^{\mathrm{a}}$ \\
\hline
\end{tabular}

\section{Keterangan:}

Huruf yang berbeda menunjukkan perbedaan yang nyata berdasarkan analisis statistik Duncan $(p<0,01)$

Analisis statistik Oneway ANOVA dan uji Duncan (Tabel 2) menunjukkan bahwa terdapat pengaruh bermakna pada kultur sel endotel yang dipapar dengan ekstrak mengkudu terhadap banyaknya ekspresi protein sitokin TNF- $\alpha$ dalam sel endotel $(p<0,01)$. Dengan pemberian ekstrak mengkudu berbagai dosis, yaitu 2,5 $\mathrm{mg} \mathrm{ml}^{-1}, 5 \mathrm{mg} \mathrm{ml}^{-1}$, dan $10 \mathrm{mg} \mathrm{ml}^{-1}$, terjadi penurunan ekspresi protein sitokin TNF- $\alpha$ pada kultur sel endotel dipapar OxLDL.

Imunohistokimia Ekspresi Protein ICAM-1 Pada Kultur Sel Endotel (HUVECs)

Hasil Immunuhistokimia pada kultur sel endotel tampak terdapat beberapa sel yang menunjukkan adanya ekspresi protein ICAM-1, diperlihatkan pada kontrol positif (Gambar 7) dengan penampakan inti sel berwarna kecoklatan dan membran sel juga berwarna kecoklatan. Pada gambar ditandai dengan panah berwarna biru. Ekspresi protein ICAM-1 yang timbul pada kultur sel kontrol positif akibat dari teraktivasinya faktor transkripsi NF-k $\beta$, hasil induksi atau pemaparan Ox-LDL.

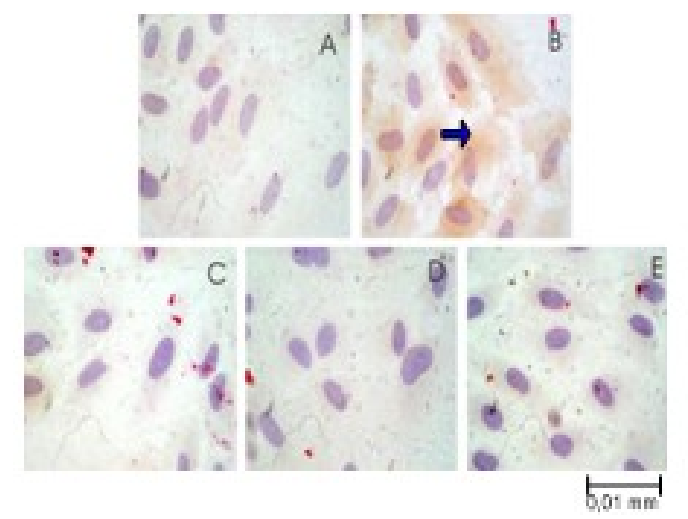

Gambar 7. Kultur HUVECs hasil imunohistokimia untuk melihat ekspresi protein ICAM-1. (A) Kontrol Negatif atau tanpa perlakuan, (B) Kontrol Positif/dipapar LDL teroksidasi $40 \mathrm{\mu g} \mathrm{ml}^{-1}$, (C),(D) dan (E) adalah HUVECs diberi ekstrak mengkudu dengan dosis berturut-turut $2,5 \mathrm{mg} \mathrm{ml}^{-1}, 5 \mathrm{mg} \mathrm{ml}^{-1}$, dan $10 \mathrm{mg} \mathrm{ml}^{-1}$ yang dipapar $\mathrm{LDL}$ teroksidasi $40 \mu \mathrm{g} \mathrm{ml}^{-1}$. Preparat diamati dengan mikroskop Olympus cx21 perbesaran 1000 kali.

Gambar hasil pengecatan imunohistokimia di atas menunjukkan bahwa dengan bertambahnya dosis ekstrak mengkudu (Gambar 10 C, D dan E) yang diberikan pada kultur sel endotel (HUVECs) maka ekspresi protein ICAM-1 semakin berkurang. Hal ini ditandai dengan intensitas warna inti sel semakin berkurang dan membran sel yang tampak kecoklatan dan semakin banyak inti sel tampak biru keunguan.

Hasil pengecatan secara imunohistokimia untuk aktivasi ICAM-1 kemudian dilakukan penghitungan sel yang ditunjukkan pada Tabel 3 . Berdasarkan penghitungan jumlah kultur sel endotel yang mengekspresikan protein ICAM-1 paling tinggi terdapat pada perlakuan kontrol positif, di mana kultur sel endotel hanya dipapar 
Ox-LDL. Perlakuan kultur sel endotel dengan pemberian berbagai dosis ekstrak mengkudu menunjukkan penurunan ekspresi protein ICAM1 , terutama pada dosis mengkudu $10 \mathrm{mg} \mathrm{ml}^{-1}$ yang merupakan dosis paling tinggi.

Tabel 3. Pemberian Ekstrak Mengkudu pada kultur Sel Endotel dipapar Ox-LDL $40 \mu \mathrm{g} \mathrm{ml}^{-1}$ Terhadap ekspresi ICAM-1

\begin{tabular}{llll}
\hline No & Perlakuan & $\begin{array}{l}\text { Jumlah } \\
\text { Sel }\end{array}$ & $\begin{array}{l}\text { Aktivasi ICAM-1 } \\
([\mathrm{X} \pm \mathrm{SD}])\end{array}$ \\
\hline 1 & $\begin{array}{l}\text { Kontrol } \\
\text { Negatif }\end{array}$ & 147 & $0,00 \pm 0,00^{\mathrm{a}}$ \\
2 & $\begin{array}{l}\text { Kontrol } \\
\text { Positif }\end{array}$ & 267 & $96,17 \pm 12,39^{\mathrm{b}}$ \\
3 & $\begin{array}{l}\mathrm{M}_{1} \\
\left(2,5 \mathrm{ng} \mathrm{ml}^{-1}\right)\end{array}$ & 223 & $3,71 \pm 6,22^{\mathrm{a}}$ \\
4 & $\begin{array}{l}\mathrm{M}_{2} \\
\left(5 \mathrm{ng} \mathrm{ml}^{-1}\right)\end{array}$ & 230 & $2,15 \pm 3,96^{\mathrm{a}}$ \\
5 & $\begin{array}{l}\mathrm{M}_{3} \\
\left(10 \mathrm{ng} \mathrm{ml}^{-1}\right)\end{array}$ & 193 & $1,42 \pm 5,09^{\mathrm{a}}$ \\
\hline
\end{tabular}

\section{Keterangan:}

Huruf yang berbeda menunjukkan perbedaan yang nyata berdasarkan analisis statistik Duncan $(p<0,01)$

Analisis statistik Oneway ANOVA dan uji Duncan menunjukkan bahwa terdapat pengaruh bermakna pada kultur sel endotel yang dipapar dengan ekstrak mengkudu terhadap banyaknya ekspresi protein ICAM-1 dalam sel endotel $(p<0.01)$. Dengan pemberian ekstrak mengkudu berbagai dosis, yaitu $2,5 \mathrm{mg} \mathrm{ml}^{-1}, 5 \mathrm{mg} \mathrm{ml}^{-1}$, dan $10 \mathrm{mg} \mathrm{ml}^{-1}$.

Pengaruh Ox-LDL terhadap aktivasi faktor transkripsi NF-K $\beta$, ekspresi protein TNF- $\alpha$ dan ICAM-1

Berdasarkan pada hasil penelitian ini dapat diketahui bahwa Ox-LDL $40 \mu \mathrm{g} \mathrm{ml}^{-1}$ berpengaruh secara nyata pada aktivasi faktor transkripsi NF$\kappa \beta$ (Tabel. 1), ekspresi protein TNF- $\alpha$ (Tabel 2), dan terhadap ekspresi ICAM-1 (Tabel 3) kultur sel endotel. Banyak penelitian yang telah membuktikan bahwa Ox-LDL berperan penting dalam memicu perkembangan patogenesis aterosklerosis. Modifikasi LDL dapat meningkatkan ekspresi beberapa protein inflamasi (sitokin), molekul adesi, chemokine, dan mediator inflamasi lainnya pada sel endotel. Hal ini dijadikan sebagai pertanda bahwa ekspresi protein serta molekul adesi muncul melalui aktivasi NF-k $\beta$ yang selanjutnya dapat memicu timbulnya aterosklerosis.

Stress oksidatif yang berasal dari Ox-LDL dapat mengaktivasi NF-k $\beta$ dan meningkatkan produksi radikal superoksida (salah satu ROS) dalam sel endotel. Proses Ox-LDL yang akhirnya dapat mengaktivasi NF-k $\beta$ juga dipengaruhi oleh reseptor untuk Ox-LDL yaitu LOX-1 (leptin-like Ox$L D L$ receptor-1) sehingga kemudian terbentuk $\operatorname{ROS}[6,7,8]$.

Brand et al., dan Collins menjelaskan bahwa NF- $\beta \beta$ yang teraktivasi dalam sel endotel berperan penting dalam patogenesis aterosklerosis. NF-к $\beta$ sebagai faktor trans-kripsi, ketika dalam keadaan non aktif, NF-k $\beta$ berada di sitoplasma dan berikatan dengan IK $\beta$ (inhibitor kappa beta). NF-k $\beta$ terdiri dari dua protein heterodimer yaitu p50 dan p65 [9, 10]. Jika mengalami stimulasi dari luar, seperti timbulnya ROS akibat Ox-LDL, IK $\beta$ yang semula berikatan dengan p50-p65 terfosforilasi dan mengalami ubiquitinasi yang akan terjadi degradasi proteasom 26S. Hal ini menyebabkan terbebasnya dimer NF-k $\beta$ (p50-p65) dari kompleks sitoplasmik NF-к $\beta-\mathrm{I} \beta \beta$ menuju nukleus. NF-k $\beta$ kemudian terikat pada gen target dan menginduksi transkripsi dan gen proinflamasi. Aktivasi NF-к $\beta$ meningkatkan ekspresi dari molekul adesi Eselectin, VCAM-1 dan ICAM-1, dan sintesis sitokin seperti TNF- $\alpha$, IL-1 $\beta$, IL-6, IL-8 dan juga COX-2 [11, 12].

Pengaruh Pemberian Ekstrak Mengkudu Pada Kultur Sel Endotel dipapar Ox-LDL Dalam Menghambat Aktivasi NF-k $\boldsymbol{\beta}$

Beberapa data hasil pengecatan secara imunohistokimia (Gambar 4) menunjukkan bahwa pemberian ekstrak mengkudu berbagai dosis pada kultur sel endotel yang dipapar OxLDL mampu menurunkan aktivasi NF-k $\beta$ secara signifikan dibandingkan dengan lkultur sel endotel kontrol positif $(p<0,01)$. Hal ini menunjukkan bahwa senyawa bioaktif antioksidan dan polifenol yang terkandung dalam mengkudu dapat menghambat oksidasi LDL sehingga tidak terjadi aktivasi NF-k $\beta$. Beberapa hasil penelitian yang telah dilakukan terhadap buah mengkudu menunjukkan bahwa di dalam mengkudu terkandung banyak antioksidan (vitamin $C$ dan E) serta senyawa polifenol yaitu 3,3'-bisdemethylpinoresinol, americanoic acid $A$ americanol A, americanin A, morindolin, dan isoprincepin [13]. Oleh karena itu, diperkirkan bahwa antioksidan dan senyawa polifenol dalam mengkudu yang berperan dalam menghambat modifikasi oksidatif LDL yang berperan penting pada patogenesis atero-sklerosis.

Mekanisme penghambatan yang dilakukan oleh mengkudu terhadap aktivasi NF-к $\beta$ adalah dengan mencegah mencegah terlepasnya ikatan I $\beta$ dengan p50-p65 dan translokasi p50-p65 dari sitoplasma ke dalam nukleus $[11,12]$. Sedangkan 
uji antar perlakuan dosis ekstrak mengkudu menunjukkan tidak terdapat beda secara bermakna. Hal ini mungkin disebabkan dosis perlakuan tidak berbeda signifikan.

Hasil perhitungan menggunakan korelasi Spearman's menunjukkan korelasi negatif secara bermakna antara aktivasi NF-k $\beta$ dan pemberian ekstrak mengkudu. Sehingga dapat dikatakan bahwa semakin besar dosis ekstrak mengkudu maka aktivasi NF-k $\beta$ semakin menurun.

Pengaruh Pemberian Ekstrak Mengkudu Pada Kultur Sel Endotel dipapar Ox-LDL Dalam Menghambat Ekspresi Protein TNF- $\alpha$

Hasil penelitian ini menunjukkan bahwa pemberian ekstrak mengkudu pada kultur sel endotel yang dipapar Ox-LDL dapat menghambat ekspresi protein TNF- $\alpha$ secara signifikan $(p<0,01)$ dibandingkan dengan kultur sel endotel perlakuan kontrol positif (dipapar Ox-LDL tanpa mengkudu). Penurunan ekspresi protein TNF- $\alpha$ pada kultur endotel yang dipapar Ox-LDL dan ditambah dengan mengkudu sangat signifikan bila dibandingkan dengan perlakuan kontrol positif $(p<0,01)$. Hal ini dapat ditunjukkan pada hasil immuno-histokimia (Gambar 6) dan penghitungan kultur sel endotel yang mengekspresikan protein TNF- $\alpha$ (Tabel 2).

Ekspresi protein TNF- $\alpha$ pada kultur sel endotel yang dipapar Ox-LDL dihambat dengan adanya ekstrak mengkudu mengandung senyawa bioaktif antioksidan dan polifenol. Adanya antioksidan dan polifenol dalam ekstrak mengkudu yang menyebabkan proses ekspresi protein TNF$\alpha$ melalui jalur faktor transkripsi NF-k $\beta$ dapat dihambat melalui penghambatan ROS yang dipicu oleh Ox-LDL. Mian-Ying menjelaskan bahwa Ekstrak etanol dari mengkudu pada berbagai konsentrasi juga dapat menghambat produksi Tumor Necrosis Factor-alpha (TNF- $\alpha$ ) yang merupakan promotor tumor endogen [14].

Pengaruh Pemberian Ekstrak Mengkudu Pada Kultur Sel Endotel dipapar Ox-LDL Dalam Menghambat Ekspresi Protein ICAM-1

Berdasarkan analisis statistik ANOVA, pemberian ekstrak mengkudu berbagai dosis menurunkan ekspresi protein ICAM-1 secara bermakna dibandingkan dengan kontrol positif $(p<0,01)$. Hal ini menunjukkan bahwa senyawa bioaktif antioksidan dan polifenol yang terkandung dalam mengkudu dapat menghambat oksidasi LDL sehingga tidak terjadi ekspresi protein ICAM-1. Sedangkan uji Duncan antar perlakuan dosis ekstrak mengkudu menunjukkan tidak terdapat beda secara bermakna.
Penelitian ini sejalan dengan penelitian sebelumnya yaitu kultur sel endotel yang dipapar dengan Ox-LDL dapat meningkatkan ekspresi molekul adesi sel, seperti ICAM-1 (intracelluler cell adhesion molecule-1), VCAM-1 (vascular cell adhesion molecule-1), dan E-selektin. Molekul adesi ini berinteraksi dengan ligan spesifik yang terekspresi pada permukaan leukosit, seperti integrin $\beta_{1}$ dan $\beta_{2}$, dan memediasi perputaran leukosit, tetap melekat pada endotel dan bermigrasi ke dalam ruang subendotel $[9,10,15]$.

Penghambatan ekspresi molekul adesi ICAM1 dengan pemberian ekstrak mengkudu mengandung senyawa bioaktif antioksidan dan polifenol sejalan dengan Cominacini yang membuktikan bahwa antioksidan menghambat ekspresi ICAM-1 dan VCAM-1 pada kultur sel endotel dipapar Ox-LDL. Antioksidan juga menurunkan ekspresi stimulus yang diinduksi ekspresi dari integrin $\beta_{1}$ dan $\beta_{2}$ pada leukosit dan adesi sel ini pada kultur sel endotel. Ekspresi adesi molekul ICAM-1 juga diregulasi oleh NF-K $\beta$ pada kultur sel. Adanya antioksidan dan senyawa polifenol dalam ekstrak mengkudu merupakan inhibitor poten yang dapat menghambat aktivasi NF-K $\beta$ sehingga ekspresi molekul adesi ICAM-1 menurun [9].

\section{KESIMPULAN DAN SARAN Kesimpulan}

Pemberian dosis ekstrak mengkudu 2,5 $\mathrm{mg} \mathrm{ml}^{-1}, 5 \mathrm{mg} \mathrm{ml}^{-1}$, dan $10 \mathrm{mg} \mathrm{ml}^{-1}$ pada kultur sel endotel yang dipapar oleh Ox-LDL dapat menghambat aktivasi faktor transkripsi NF-k $\beta$, ekspresi protein sitokin TNF- $\alpha$, dan ekspresi protein ICAM-1 pada kultur sel endotel manusia (HUVECs) dipapar Ox-LDL $40 \mathrm{\mu g} \mathrm{ml}^{-1}$ sebagai agen inflamasi yang dapat menimbulkan terjadinya aterosklerosis secara signifikan $(p<0,01)$. Senyawa bioaktif antioksidan dan polifenol yang terkandung dalam mengkudu diduga dapat menghambat oksidasi LDL sehingga tidak terjadi ekspresi aktivasi NF-k $\beta$, ekspresi protein TNF- $\alpha$, dan protein ICAM-1.

\section{Saran}

Metode pengukuran secara imunohistokimia masih bersifat semi kuantitatif dalam menganalisis aktivasi NF-k $\beta$, ekspresi protein inflamasi TNF- $\alpha$ serta ICAM-1, sehingga perlu analisis lebih akurat menggunakan EMSA (Electrophoretic Mobility Shift Assay) untuk mengetahui pengikatan protein-DNA atau RT PCR/RNA untuk mendeteksi gen target. Perlu penelitian lebih lanjut menggunakan ekstrak murni zat bioaktif antioksidan dan polifenol dari mengkudu untuk 
membuktikan zat bioaktif tersebut dapat menghambat kerja Ox-LDL dalam menimbulkan ROS, menghambat aktivasi NF-k $\beta$, ekspresi protein inflamasi TNF- $\alpha$ serta ICAM-1 yang menyebabkan penyakit aterosklerosis.

\section{DAFTAR PUSTAKA}

1. Ross, R. 1999. Atherosclerosis- An Inflammatory Disease. The New England Journal of Medicine. No. 2 Vol. 340:115-126.

2. Middleton, E., K. Chithan, C.T. Theoharis. 2000. The Effects of Plant Flavonoids on Mammalian Cells: Implications for Inflammation, Heart Disease, and Cancer. Department of Pharmacology and Experimental Therapeutics. Tufts University School of Medicine. Boston. Massachusetts (T.C.T.) Vol. 52 Issue 4:673-751.

3. Wijayakusuma, H. 2001. Penyembuhan Dengan Mengkudu (Morinda citrifolia L.). Penerbit Milenia Populer. Jakarta.

4. Kamiya, K., Y. Tanaka, H. Endang, M. Umar, T. Satake. 2004. Chemical Constituent of Morinda Fruits Inhibit Cooper-induced Low Density Lipoprotein Oxidation. Journal Agriculture Food Chemistry. 22.52.19:58435848.

5. Arjita, I P. D., M.A. Widodo, E. Widjajanto. 2002. Pengaruh Kadar Glukosa Tinggi Terhadap Sintesa Nitric Oxide dari Human Umbilical Vein Endothelial Cells (HUVECs) Culture Dengan Teknik Bioassay. BIOSAIN. Vol.2. No.1.

6. Cominacini, L., F.P. Anna, G. Ullise, 2000. Oxidized Low Density Lipoprotein (Ox-LDL) Binding to Ox-LDL Receptor-1 in Endothelial Cells Induces The Activation Of NF-kB through an Increased Production of Intracellular ROS. The Journal Of Biological Chemistry. Vol. 275 No. 17:12633-12638.

7. Foncea, R., C. Carvajal, C. Almarza, F. Leighton. 1999. Endothelial Cell Oxidative Stress and Signal Transduction. Laboratorio de Citologia Bioquimica y Lipidos, Facultad de Ciencias Biológicas, Universidad Católica de Chile, Santiago.

8. Tardif, J. C. 2003. Oxidative Stress and Coronary Heart Disease. Cardiology Rounds. Vol 7. issue 9.

9. Brand, K., P. Sharon, R. Gerhard, B. Armin. 1996. Activated Transcription Factor NuclearKappa B is Present in The Atherosclerotic Lesion. J. Clin. Invest. Vol. 97. 7:1715-1722.
10. Collins, T., I.C. Myron. 2001. NF-kB: Pivotal Mediator or Innocent bystander in Atherogenesis? J Clin Invest. Vol. 107. No. 3:255-264.

11. Tak, P. P., S. F. Gary. 2001. NF-кß: a Key Role in Inflammatory Diseases. The Journal of Clinical Investigation. Vol. 107 No.1.

12. Ho, E. 2002. NF-KB-What Is It and What's The Deal With Radicals? Linus Pauling Institute Scientist. Department Of Nutrition And Food Management. Oregon State University.

13. Aviram, M. 2003. Polyphenolic Flavonoids Content and Antioxidant Activities Of PJ and various Fruit Juices [Pomegranate Juice(PJ), PJ/Blueberry, MOBETA, Orange-CarrotBanana, Orange-Carrot, Mango, Apple-kiwi, and Tahitian NONI]: a comparative Study. The Lipid Research Laboratory. Technion Faculty. The Rappaport Family Institute for research in the medical science and Rambam medical Center. Haifa. Israel.

14. Miang-Ying, W., J.W. Brett, C.J. Jensen. 2002. Morinda citrifolia (Noni): A Literature Review and Recent Advances In Noni Research. Acta Pharmacol Sinica Shanghai Institute of Materia Medica Chinese Academy Of Science. Dec. 23. 12:1127-1141.

15. Carr, A., B. Zhu, B. Frei. 2000. Potential Antiatherogenic Mechanisms of Ascorbate (Vitamin C) and $\alpha$-Tocopherol (Vitamin E). Circulation Research. 87:349-354. 